\title{
CORPORATE GOVERNANCE POLICY IMPLEMENTATION ANALYSIS USING D. WAYNE TAYLOR THEORY. CASE STUDY: DENTAL AND ORAL HOSPITAL BY FACULTY OF DENTISTRY UNIVERSITAS INDONESIA (RSKGM FKG UI) IN 2019
}

\author{
*Yusnur Mauliana Dranie Putri, **Masyitoh \\ *Health Policy and Administration, Faculty of Public Health, Universitas Indonesia, \\ Kampus Depok, Jawa Barat, 16425, Indonesia \\ ** Health Policy and Administration, Faculty of Public Health, Universitas Indonesia, \\ Kampus Depok, Jawa Barat, 16425, Indonesia
}

Email : olindranie@gmail.com

\begin{abstract}
Corporate Governance is a term that is related to the direction and control of an organization, institution, or function, to fit the goals and expectations of decision makers. This research aims to conduct an analysis of corporate governance using D. Wayne Taylor's theory by conducting a case study at the Dental and Oral Hospital by Faculty of Dentistry Universitas Indonesia (RSKGM FKG UI). The design of this research is qulitative analysis with methods of collection data through document review and in-depth interview. The results of the research are reflected in nine principles that are recognized by six incompatible principles, two principles that are appropriate, and one principle that cannot be seen in accordance with the requirements in RSKGM FKG UI that have not supported yet. Two principles that are appropriate are: the principle of the Board-CEO Relationship and the principle of the Ownership Needs.
\end{abstract}

Keywords: Governance, corporate governance, D. Wayne Taylor

\begin{abstract}
Abstrak. Corporate Governance merupakan merupakan suatu istilah yang terkait dengan mekanisme mengarahkan dan mengendalikan suatu organisasi, lembaga, ataupun fungsi, agar sesuai dengan tujuan dan harapan para pembuat keputusan. Penelitian ini bertujuan untuk melakukan analisis corporate governance menggunakan teori D. Wayne Taylor dengan melakukan studi kasus pada Rumah Sakit Khusus Gigi dan Mulut Fakultas Kedokteran Gigi Universitas Indonesia (RSKGM FKG UI). Desain penelitian ini adalah analisa kualitatif dengan metode pengumpulan data melalui telaah dokumen dan wawancara mendalam. Hasil penelitian menggambarkan bahwa dari sembilan prinsip diketahui bahwa enam prinsip belum sesuai, dua prinsip sudah sesuai, dan satu prinsip tidak dapat dilihat kesesuaiannya karena kondisi di RSKGM FKG UI yang belum mendukung. Dua prinsip yang sudah sesuai yaitu: prinsip Hubungan Dewan dengan Direktur dan prinsip Kebutuhan Pemilik.
\end{abstract}

Kata kunci: Pemerintah, corporate governance, D. Wayne Taylor

\section{INTRODUCTION}

To achieve the aim of good hospital governance in Indonesia, hospital management functions must be implemented on the basis of several principles, including transparency, accountability, independence and responsibility, as well as equality and justice (UU No. 44/2009). In his research on health-care governance in 2000, D. Wayne Taylor outlined nine principles for achieving effective health-care governance. Knowing what governance is, achievement of strategic ends, Board-CEO relationship, unity of direction, unity of command, unity of accountability/responsibility, Ownership needs, self-improvement, and understanding the cost of governance are the nine principles (Taylor, 2000).
These nine principles are then used as a research foundation for comparing hospital governance in New Zealand to hospital governance in the Czech Republic (Ditzel et al., 2006) and comparing hospital governance in Ghana (Ditzel et al., 2006). (Abor, et al., 2008).

According to Ditzel's research on hospital governance in New Zealand and the Czech Republic, the implementation of hospital governance in the Czech Republic is still not optimal. Board-CEO relationship is the only principles of D. Wayne Taylor's nine principles of governance that are now in line with the conditions of hospitals in the Czech Republic, while the other eight principles are still unsuitable. New Zealandhospital governance can be defined as better governance, 
with many principles in line with the theory, including: knowing what governance is, achievement of strategic ends, Board-CEO relationship, unity of direction, unity of command, unity of accountability/responsibility, ownership needs, self-improvement, and understanding the cost of governance. In his research, Joshua Abor compares and contrasts government and private hospitals in Ghana. The study indicates that Ghana's hospital governance was good. Government hospitals have complied to Taylor's nine principles of governancewhile private hospitals have not complied with the principles of unity of command, selfimprovement and quality control, and understanding the cost of governance.

Dental and Oral Hospital (RSKGM) is a health-care facility that offers individual dental and oral health services (PMK No. 1173/2004). The Dental and Oral Health Hospital, Faculty of Dentistry, Universitas Indonesia (RSKGM FKG UI) is a facility that offers individual dental and oral health services as well as a variety of other dental specialist services which is located on Salemba Raya Street No. 4 in Central Jakarta. RSKGM FKG UI also runs a separate clinic to support the practice of undergraduate and specialist students FKG UI clinicians.

The implementation and management of RSKGM FKG UI, as a complex teaching hospital, are also subject to a number of conditions that can pose a risk. Internal and external parties that are directly linked to hospital performance would suffer as a result of poor governance. Bad hospital performance would damage the hospital's overall reputation, lose public confidence, reduce the number of patient visits, increase the risk of financial loss, and influence decision-making by external parties.

According to the 2018 RSKGM FKG UI Annual Report, many obstacles exist in the implementation of core hospital service activities, including late payment of employee remuneration and medical services for practicing doctors; hospital service revenue that does not always meet the target; employees who do not meet the hospital qualifications; and the status of the hospital. The constraints discovered by researchers at the study site are aligned with D. Wayne Taylor's nine governance principles. Based on these circumstances, researchers were interested in analyzing the implementation of corporate governance that occurred at RSKGM FKG UI based on nine principles suggested by D. Wayne Taylor.

The research will take a qualitative approach, with data being collected through in-depth interviews and document analysis. The overall objectives of this research is to conduct a case study at RSKGM FKG UI in 2019 to analyze corporate governance using D. Wayne Taylor's theory. The specific focus of this research is to gain an overview of how the principles are applied.

\section{METHOD}

A case study is a type of research technique that is used to gain a better understanding of something that attracts interest, such as social structures, actual events, or the experiences of people who are in the context of a case. Case studies are being developed in the social sciences, and in practice-oriented fields such as environmental studies, education, and industry, in the hopes of capturing the essence of a particular case (Johanson, 2003). This research takes a qualitative approach to its analysis. In-depth interviews, which aim to see a comprehensive description of the object of research and study secondary data to ensure that the description of the object is in accordance with predetermined standards, are one method of data collection that can be used. This research is descriptive study that seeks to describe or explain in detail the application of hospital governance.

The research was conducted at RSKGM FKG UI in June 2019 with the application of RSKGM FKG UI's governance principles in 2019 as a research analysis unit. The snowball sampling technique was used to conduct in-depth interviews with informants. Interviews will continue to be conducted with informants suggested by previous informants until all of the data desired by the researcher has been gathered. The interview results are used to illustrate the conditions for the application of good governance principles in the study area. Meanwhile, document review is conducted out by analyzing data in the form of the hospital's vision, mission, values, and objectives; a list of hospital policies; strategic planning; hospital performance reports; the main duties and functions of hospital employees; organizational structure; Standard Operating Procedure (SOP) for finance and employee recruitment; financial reports and supporting evidence; and list of employee training and competencies.

The data collection method described in tabular form in accordance with the respective principles to be studied. The following is a table of data collection methods along with target informant data:

Table 1. Data Collection Method

\begin{tabular}{|c|c|c|c|c|c|}
\hline No. & Principle & Method & & Source/Informant & Instrument \\
\hline 1. & $\begin{array}{l}\text { Knowing What } \\
\text { Governance is; }\end{array}$ & $\begin{array}{l}\text { In-depth } \\
\text { Interview } \\
\text { and } \\
\text { Document } \\
\text { Review }\end{array}$ & $\begin{array}{l}3 . \\
4 .\end{array}$ & $\begin{array}{l}\text { Director's Decree } \\
\text { No.678/SK.F2.RSKGM/U } \\
\text { I/2019; } \\
\text { Legal Standing of } \\
\text { RSKGM; } \\
\text { Dean of FKG UI; } \\
\text { Director of RSKGM FKG } \\
\text { UI }\end{array}$ & $\begin{array}{c}\text { Interview } \\
\text { Guidelines, } \\
\text { Checklist } \\
\text { Sheets }\end{array}$ \\
\hline 2. & $\begin{array}{l}\text { Achievement } \\
\text { of Strategic } \\
\text { Ends; }\end{array}$ & $\begin{array}{c}\text { Document } \\
\text { Review }\end{array}$ & 1. & $\begin{array}{l}\text { Strategic Plan of RSKGM } \\
\text { FKG UI; } \\
\text { The Work Program of } \\
\text { RSKGM FKG UI }\end{array}$ & $\begin{array}{l}\text { Checklist } \\
\text { Sheets }\end{array}$ \\
\hline
\end{tabular}




\begin{tabular}{|c|c|c|c|c|c|}
\hline 3. & $\begin{array}{l}\text { Board-CEO } \\
\text { Relationship; }\end{array}$ & $\begin{array}{l}\text { In-depth } \\
\text { Interview }\end{array}$ & $\begin{array}{l}1 . \\
2 . \\
3 .\end{array}$ & $\begin{array}{l}\text { Dean of FKG UI; } \\
\text { Director of RSKGM FKG } \\
\text { UI; } \\
\text { Deputy Director of } \\
\text { Finance, General } \\
\text { Administration, and } \\
\text { Human Resources }\end{array}$ & $\begin{array}{l}\text { Interview } \\
\text { Guidelines }\end{array}$ \\
\hline 4. & $\begin{array}{l}\text { Unity of } \\
\text { Direction; }\end{array}$ & $\begin{array}{l}\text { In-depth } \\
\text { Interview } \\
\text { and } \\
\text { Document } \\
\text { Review }\end{array}$ & $\begin{array}{l}1 . \\
2 . \\
3 . \\
4 . \\
4 . \\
6 .\end{array}$ & $\begin{array}{l}\text { Organization Structure; } \\
\text { Formal Procedure; } \\
\text { Strategic Plan of RSKGM } \\
\text { FKG UI; } \\
\text { Work Program of RSKGM } \\
\text { FKG UI; } \\
\text { Dean of FKG UI; } \\
\text { Director of RSKGM FKG } \\
\text { UI; }\end{array}$ & $\begin{array}{c}\text { Interview } \\
\text { Guidelines, } \\
\text { Checklist } \\
\text { Sheets }\end{array}$ \\
\hline 5. & $\begin{array}{l}\text { Unity of } \\
\text { Command; }\end{array}$ & $\begin{array}{l}\text { In-depth } \\
\text { Interview }\end{array}$ & $\begin{array}{l}1 . \\
2 . \\
3 .\end{array}$ & $\begin{array}{l}\text { Dean of FKG UI; } \\
\text { Director of RSKGM FKG } \\
\text { UI; } \\
\text { Deputy Director of } \\
\text { Finance, General } \\
\text { Administration, and } \\
\text { Human Resources }\end{array}$ & $\begin{array}{c}\text { Interview } \\
\text { Guidelines }\end{array}$ \\
\hline 6. & $\begin{array}{l}\text { Unity of } \\
\text { Accountability/ } \\
\text { Responsibility; }\end{array}$ & $\begin{array}{l}\text { In-depth } \\
\text { Interview } \\
\text { and } \\
\text { Document } \\
\text { Review }\end{array}$ & $\begin{array}{l}. \\
2 . \\
3 . \\
4 . \\
5 . \\
6 . \\
7 .\end{array}$ & $\begin{array}{l}\text { The Main Duties and } \\
\text { Functions; } \\
\text { Financial Procedure of } \\
\text { RSKGM FKG UI; } \\
\text { RKAT RSKGM FKG UI; } \\
\text { Financial Report; } \\
\text { Dean of FKG UI; } \\
\text { Director of RSKGM FKG } \\
\text { UI; } \\
\text { Deputy Director of } \\
\text { Finance, General } \\
\text { Administration, and } \\
\text { Human Resources }\end{array}$ & $\begin{array}{c}\text { Interview } \\
\text { Guidelines, } \\
\text { Checklist } \\
\text { Sheets }\end{array}$ \\
\hline 7. & $\begin{array}{l}\text { Ownership } \\
\text { Needs; }\end{array}$ & $\begin{array}{l}\text { In-depth } \\
\text { Interview } \\
\text { and } \\
\text { Document } \\
\text { Review }\end{array}$ & $\begin{array}{l}2 . \\
3 .\end{array}$ & $\begin{array}{l}\text { Director's Decree } \\
\text { No.678/SK.F2.RSKGM/UI } \\
\text { /2019; } \\
\text { Dean of FKG UI; } \\
\text { Director of RSKGM FKG } \\
\text { UI }\end{array}$ & $\begin{array}{c}\text { Interview } \\
\text { Guidelines, } \\
\text { Checklist } \\
\text { Sheets }\end{array}$ \\
\hline 8. & $\begin{array}{l}\text { Self- } \\
\text { improvement; }\end{array}$ & $\begin{array}{l}\text { In-depth } \\
\text { Interview } \\
\text { and } \\
\text { Document } \\
\text { Review }\end{array}$ & $\begin{array}{l}2 . \\
3 . \\
4 .\end{array}$ & $\begin{array}{l}\text { List of employees who } \\
\text { attended self-improvement } \\
\text { training; } \\
\text { Dean's advice and } \\
\text { recommendation function; } \\
\text { Dean of FKG UI; } \\
\text { Director of RSKGM FKG } \\
\text { UI }\end{array}$ & $\begin{array}{c}\text { Interview } \\
\text { Guidelines, } \\
\text { Checklist } \\
\text { Sheets }\end{array}$ \\
\hline 9. & $\begin{array}{l}\text { Understanding } \\
\text { The Cost of } \\
\text { Governance }\end{array}$ & $\begin{array}{l}\text { In-depth } \\
\text { Interview } \\
\text { and } \\
\text { Document } \\
\text { Review }\end{array}$ & $\begin{array}{l}2 . \\
3 .\end{array}$ & $\begin{array}{l}\text { Director's Decree } \\
\text { No.678/SK.F2.RSKGM/U } \\
\text { I/2019; } \\
\text { Dean of FKG UI; } \\
\text { Director of RSKGM FKG } \\
\text { UI }\end{array}$ & $\begin{array}{c}\text { Interview } \\
\text { Guidelines, } \\
\text { Checklist } \\
\text { Sheets }\end{array}$ \\
\hline
\end{tabular}

The information gathered from in-depth interviews and document review was processed in stages. The following steps are taken to conduct in-depth interviews:

1. Listen to the recordings of the interviews and write as transcript.

2. Sorting data into categories based on a given topic.

3. Create an interview matrix by rereading, comprehending, and researching the transcript in order to compare it to research questions.

4. Analyze data and present it in the form of information that is easy to read and understand. Complete analysis results are presented, along with direct quotations from research informants.

The results of the checklist were used for document review, and they were examined to strengthen the findings of the in-depth interviews.

\section{RESULTS AND DISCUSSION}

Researchers interviewed the Dean of the FKG UI, the Director of the RSKGM FKG UI, and four (4) employees of the RSKGM FKG UI in 2019 about the governance of the RSKGM FKG UI. The following table summarizes the characteristics of the interviewees:

Table 2. Characteristic of The Interviewees Data

\begin{tabular}{ccc}
\hline Informant & Sex & Education \\
\hline Informant 1 & Female & Doctoral \\
Informant 2 & Female & Doctoral \\
Informant 3 & Female & Master's \\
Informant 4 & Female & Bachelor's \\
Informant 5 & Female & Bachelor's \\
Informan 6 & Male & Associate \\
\hline
\end{tabular}

\section{Knowing What Governance is}

RSKGM FKG UI has developed a vision, mission, and goals for the hospital based on secondary data and interviews. The definition of governance is also clearly defined in the decree and report. From the fundamental factors that led to the formation of RSKGM FKG UI and how its operational activities are governed by Hospital Bylaws. When defined, governance is the structure and function of an organization that regulates and enforces policies and uses authority to make decisions on its behalf (Umbdenstock \& Hageman, 1991; Holland, Ritvo, \& Kovner, 1997; Pointer \& Orlikoff, 1999). This theory is also supported by the governance concept proposed by (Tabish, 2012), which states that having a clear mission and a culture oriented toward achieving goals is one of the core elements required to achieve excellence in hospital governance. According to the Indonesian Institute for Corporate Governance (IICG), governance is a term that refers to the mechanism of directing and controlling an organization, institution, or function so that it meets the goals and expectations of decision makers.

When compared to the conditions in RSKGM FKG UI, the governance theory described is adequate. The ownership of RSKGM FKG UI on the foundation for the formation, the vision, mission, objectives, and understanding of good governance written in the report and the Director's Decree demonstrate that the Director, Board, and Owner already have a sufficient understanding of important rules and principles that the organization must fulfill in order to run as intended. This indicates that the actors' understanding of governance is adequate. During the research process, the researcher discovered inappropriate conditions, specifically RSKGM FKG UI's unofficial status at UI, whether as a UKK with limited flexibility, full flexibility, or only as an academic support element for 
FKG UI. This is significant because it pertains to RSKGM FKG UI's rights and obligations to FKG UI and UI.

\section{Achievement of Strategic Ends}

According to the findings of secondary data research and in-depth interviews, RSKGM FKG UI had a strategic plan but still no work program for all units. According to Wodern's research, there is a strong relationship between strategic planning and organizational effectiveness (Carver, 1990; Bradshaw et al., 1992). This explains why strategic planning is necessary in an organization: the better the strategic plan, the better the organization's performance (Carver, 1990a). If the organization already has a strategic plan, it is necessary to create a work program to ensure that the work is more structured, effective, and completed on time.

The work program also serves as an indicator to demonstrate that the strategic planning that has been prepared is achievable through a series of predetermined steps. According to the Strategic Plan of RSKGM FKG UI in 20155-2019, the implementation of the principle of achieving strategic goals at RSKGM FKG UI has been quite successful. Currently, RSKGM FKG UI does not have a work program for all units, so the success of strategic plans cannot be measured, and the work done is not standardized.

\section{Board-CEO Relationship}

According to hospital bylaws, the FKG UI Dean acted as a representative for the owner and the Supervisory Board of RSKGM FKG UI. As a result, the principle of the Board-CEO Relationship can be described through the reporting made by the Director of RSKGM FKG UI to the FKG UI Dean and the perception of the relationship that exists. The Director reports in writing once a year in the form of annual reports, while quarterly reports are carried out in the form of raw data that has not been processed and reported to the Dean of the FKG UI. Monthly reports are completed through regular one-month meetings with the unit's head and quarterly meetings with each unit. According to the informants' perceptions, the relationship has been good, and disagreements can be resolved through meetings and consensus.

Communication within the organization is regarded as critical to the successful implementation of organizational change (DiFonzo \& Bordia, 1998). Because an organization will be effective and perform well if its members, particularly its Board of Directors and CEO, have mutual trust in one another (Likert, 1961; Gillies, 1992). Poorly managed change communication breeds rumors and resistance to change, exacerbating the negative aspects of change (DiFonzo et al., 1994; Smelzer \& Zener, 1992). Based on previous research, the relationship that occurred at
RSKGM FKG UI can be classified as adequate.

\section{Unity of Direction}

According to the findings of the research, RSKGM FKG UI already has an organizational structure that was approved directly by the Dean of FKG UI on June 20, 2019. The objectives of RSKGM FKG UI can also be found in the Hospital Bylaws RSKGM FKG UI, while the target of RSKGM FKG UI can be found in the Strategic Planof RSKGM FKG UI. A comparison of targets and achievements in 2018 was made to determine how many of the RSKGM FKG UI targets had been approached. The creation of the target and achievement comparison matrix was hampered by the researcher's limited data, which resulted in some performance data being left blank, resulting in a comparison of targets and achievements that did not represent the overall principle.

According to the findings of Ditzel (2006)'s research, the Director and the Supervisory Board must collaborate to achieve goals; good governance necessitates the presence of only one Supervisory Board, one Director, one strategic plan, and one vision and mission at a time. According to (Fayol, 1949), unity of direction refers to unity or cohesion within and across all elements of organizational governance. Everyone in an organization must be pulling in the same direction, working toward a common goal with a coordinated and focused effort (NCERT, 2015). According to this theory's explanation, the application of the principle of unity of direction in RSKGM FKG UI is still not optimal. This is because there are still key indicators that have not been approached, such as achievement data per unit in 2018, which has not been collected, leaving researchers with limitations and unable to assess the percentage of target success in 2018.

\section{Unity of Command}

Based on the findings of in-depth interviews, a description of the communication and delivery of instructions at RSKGM FKG UI can be seen. Coordination meetings are used for communication, and instructions from superiors to subordinates are delivered smoothly and with prior confirmation from the executing employee. According to the research (Ditzel, 2006), decision-making authority must follow a straight line and flow from the top down in the organizational structure. According to (Fayol, 1916), an employee must accept orders from only one supervisor for any action. According to the concept of unity of command, each member of the organization must report to one and only one leader (Pfiffner \& Presthus, 1953).

When the theory is compared to the conditions in RSKGM FKG UI, the application of the principle of unity of command can be classified as optimal. The 
flow of instruction delivery has been running from top to bottom, communication has been well established through meetings and consensus, work has been completed according to instructions, and there is a confirmation process before committing instructions. According to the findings of an interview with one of the informants, instructions were sometimes not completed on time or late due to the high employee workload.

\section{Unity of Accountability/Responsibility}

Based on the findings of the research, RSKGM FKG UI has fulfilled several indicators of the unity principle of accountability and responsibility. The hospital's internal scope is the responsibility of the Director of the RSKGM FKG UI, while the external scope is the responsibility of the Dean of the FKG UI. The Director's Decree also regulates the Director's authority in maintaining RSKGM FKG UI's accountability and in maintaining and safeguarding wealth. RSKGM FKG UI's financial reports to date have only consisted of records of revenues and expenses. Meanwhile, the person in charge of the financial statements has been described in the SOP of the Dean's approved Financial Report.

According to (Anderson, 1984), accountability in organizational theory is the responsibility of subordinates for performance directly to superiors, and superiors are directly responsible for the performance of subordinates who are supervised. According to (Schiavo Campo \& Tomasi, 1999 in Mardiasmo: 2006), accountability is the provision of information and disclosure to interested parties on financial activities and performance. Meanwhile, (Lloyd et al., 2007) define accountability as a series of processes undertaken by an organization in making a commitment to respond to and balance the needs of stakeholders in decision-making processes and activities, as well as fulfilling commitments.

When adjusted to the existing theory, the condition of RSKGM is adequate to fulfill the indicators of the lines of accountability, the Director's authority in preparing programs and using the budget, and the person in charge of financial reports. Financial report indicators based solely on income and expenditure cannot be considered good. A non-profit entity's financial statements should include the following items, according to Statement of Financial Accounting Standards (PSAK) Number 45 concerning Non-Profit Organizations: a statement of financial position (balance sheet) at the end of the period, a report on activities for the reporting period, a cash flow statement for the reporting period, and financial statement notes. This PSAK cannot also be used as a guide for the financial reports of RSKGM FKG UI because the hospital's status is still unknown on the UI campus.

\section{Ownernership Needs}

Based on the findings of the research, the indicators of success in applying the principle of Ownership Needs have been approached. According to Hospital ByLaws Part Two, Article 12 Ownership, RSKGM FKG UI is a UI-owned hospital, with the Chancellor as the leader and the highest person in charge of UI, representing ownership to the Dean of FKG UI. The Hospital ByLaws of RSKGM FKG UI serve as a policy to regulate the appointment and appointment process of the Board and the parties entitled to do so, the owner's authority, the monitoring function, and reports that the monitoring function is further discussed in routine meetings that apply to all directors and other scheduled meetings.

According to (Carver, 1990), conducting tests on organizational activities against the mission and values is a standard examination of the organization's direction, which is primarily the responsibility of the organization's owner. According to Joshua Abor's (2008) research, the board of directors is placed in a position of trust and is in charge of safeguarding the owner's investment, is expected to do a good job (Donaldson \& David, 1991), and is required to act as the owner's representative. When compared to the conditions in RSKGM FKG UI, the theory described can be classified as appropriate; in other words, the application of the principle of owner needs at RSKGM FKG UI has been properly implemented.

\section{Self-improvement}

Based on the findings of the research, it is known that 7 trainings were held in 2019. Two of them are part of the work program and are completed on time; the other five are not part of the program and are provided by third parties. Meanwhile, according to the work program, 11 internal trainings and 4 external trainings have to be implemented as of June 2019. According to (Taylor, 2000), training is required to ensure quality management and continuous improvement, as the hospital's philosophy must permeate all aspects. This is due to the fact that hospitals are not only economic entities, but also social entities (Saltman, 1997).

When compared to existing theories and research, the training program organized by RSKGM FKG UI is adequate in accordance with the principles of selfdevelopment. Some internal and external trainings are still not being held in accordance with the work program, affecting RSKGM FKG UI's level of achievement in relation to the targets that have been set. The Dean of the FKG UI's discussion on the monitoring function was previously discussed in the Ownership needs. 


\section{Understanding The Cost of Governance}

According to the findings of interviews and document review, RSKGM FKG UI's financial reports have never been audited, either internally or externally. As a result, no action is taken in response to the audit findings and recommendations. Personal costs of board members, board meeting costs, board support employee activity costs, board error costs, and costs associated with ineffective management are the five basic costs of the Supervisory Board, according to (Carver, 1990). According to Joshua Abor's (2008) research, other important elements in hospital governance should include costs for external audits and audit committee fees. According to RSKGM FKG UI's Organizational Structure, Dean's Decree Number 030 of 2019, the Supervisory Board sits between the Dean and the Director. The principle of understanding the cost of governance cannot be applied yet at RSKGM FKG UI because there is no special account for Supervisory Board fees, only accounts for routine meetings, according to an examination of financial reports. RSKGM FKG UI has never been audited by an external auditor, so there is no separate budget for the external auditor's and audit committee's fees.

\section{CONCLUSION}

Based on the result of the research, the following conclusions can be drawn:

1. The application of the principle of knowing what governance is in RSKGM FKG UI is characterized by the existence of a vision, mission, objectives, and governance understanding written in the report and the Director's Decree. According to Rector's Decree No. 0708/SK.R.UI /2011 on the Appointment of Head of Academic Business Units at the Universitas Indonesia, RSKGM FKG UI has not had an official status yet at UI because no new regulations have been enacted to accommodate this.

2. The preparation of a Strategic Plan for the period 2015-2019 marks the implementation of the principle of achieving of strategic ends at RSKGM FKG UI. There are no definite steps that can be taken to meet the target because each unit's work program has not been fully compiled and reported,

3. The application of the Board-CEO relationship principle at RSKGM FKG UI, in which the Council is represented by the Dean of the FKG UI, has been demonstrated through internal meetings and inter-unit meetings held on a monthly basis. The Director also reports to the Dean on a monthly or quarterly basis.

4. The principle of unity of direction has been implemented at RSKGM FKG UI, as evidenced by the existence of an organizational structure endorsed by the FKG UI Dean and the objectives outlined in Hospital Bylaws. Due to the limited performance data per unit, the success of meeting the 2018 target cannot be described as a whole at this time. Some of the data on the accomplishments obtained have reached the target.

5. The application of the principle of unity of command is carried out at RSKGM FKG UI by holding regular meetings, the delivery of instructions goes from top to bottom, and instructions that are conveyed are carried out first through a confirmation process to minimize mistakes. The issue that frequently arises with this principle is that the instructions delivered are not completed on time or are completed late.

6. RSKGM FKG UI has carried out the principle of unity of accountability/responsibility, as evidenced by the existence of regulations governing the division of responsibilities, the Director's authority in preparing programs and using the budget, and the person in charge of financial reports. The RSKGM FKG UI financial report, which consisted entirely of revenues and expenditures, does not achieve the financial reporting standards outlined in PSAK Number 45. This is due to the fact that RSKGM FKG UI's status at UI is not official yet.

7. The application of the principle of ownership needs at RSKGM FKG UI is carried out with the existence of regulations governing the process of appointment and appointment of the Board, regulations governing the authority of the Owner, the monitoring function that regulated in RSKGM FKG UI internal regulations, and reports that the monitoring function is further discussed in routine meetings. This rule should apply to all board meetings and other scheduled meetings.

8. The principle of self-improvement is implemented at RSKGM FKG UI through the implementation of training both internally and externally. There are still several internal and external trainings that have not been held in accordance with the work program, negatively impacting to the RSKGM FKG UI's level of achievement against the targets set for 2019.

9. The principle of understanding the cost of governance cannot be applied yet at RSKGM FKG UI because according to the financial report examination there is no special account for the Supervisory Board's fees, only accounts for routine meetings. Furthermore, because RSKGM FKG UI has never been audited by an external auditor, there is no separate budget for the costs of the external auditor and the audit committee. 


\section{RECOMMENDATIONS}

1. The Dean and Director of the RSKGM FKG UI provided an update on the RSKGM FKG UI's status in the UI environment, as stated in the Chancellor's Decree No. 0708/SK.R.UI/2011 concerning the Appointment of the Chairperson of the Academic Business Unit within Universitas Indonesia.

2. The Director compiles a policy requiring for each unit to create a work program for one year and submits it at the start of the year or, at the very least, before submitting the RSKGM FKG UI quarterly report to the FKG UI Dean.

3. Every month/quarter/year, data storage reports from each unit in the hospital should be centralized in one location and properly archived in accordance with archive storage standards. This is done to make the report more accessible and to improve the effectiveness of the evaluation time.

4. The Deputy Director of Finance, General Administration, and Human Resources, supported by the Head of Finance, General Administration, and Human Resources, conducts a workload analysis on a regular basis to avoid overburdening staff and to develop plans to address these issues.

5. With the additional help of their staff, the Deputy Director of Finance, General Administration, and Human Resources should began attempting to compile financial reports in accordance with PSAK No. 45 so that RSKGM FKG UI's financial reports are in accordance with standards and ready if they are to change their status to UKK with full flexibility.

6. The HR department should plan a work training program based on RSKGM FKG UI's capacity and organize training based on the work program's objectives.

\section{REFERENCES}

1. Putri, Yusnur, M. D. (2019). Analisis Corporate Governance Menggunakan Teori D. Wayne Taylor. Studi Kasus: Rumah Sakit Khusus Gigi dan Mulut Fakultas Kedokteran Gigi Universitas Indonesia Tahun 2019. Skripsi. Program S1 Ekstensi Kesehatan Masyarakat Universitas Indonesia. Depok.

2. Aseweh Abor, P. Abekah-Nkrumah, G. Joshua, A. (2008). An examination of hospital governance in Ghana. Leadership in Health Services, 21(1), 4760. https://doi.org/10.1108/17511870810845905

3. Carver, C. S. (1990). Boards that make a difference. England: Oxford Jossey-Bass,

4. Cavens, K., Kidombo, H., \& Gakuu, C. (2016).
Professional development in monitoring and evaluation and result utilization in meru region in Kenya. European Scientific Journal, ESJ, 12(23), 309. https://doi.org/10.19044/esj.2016.v12n23p309

5. Craig, Gordon A., George, Alexander L. (1995). Force and statecraft: Diplomatic problems of our time foreign affairs. New York: Oxford University Press.

6. Bogue, R. J., Hall, C. H., \& Forgia, G. M. La. (2007). Hospital governance in Latin America: results from a four nation survey hospital governance in Latin America results from a four nation survey.

7. Daniels, N., \& Sabin, J. (1997). Limits to health care: fair procedures, democratic deliberation, and the legitimacy problem for insurers millions of Americans are finding out that when they are ill, neither they nor their physicians may have the authority to make decisions about. Philosophy and Public Affairs, 26(4), 303-350.

Degroote, M. G., \& Taylor, D. W. (1993). Facts, myths and monsters: understanding the principles of good governance. International Journal of Public Sector Management, 13 No. 2, 108-124.

8. Ditzel, E., Štrach, P., \& Pirozek, P. (2006). Health research policy and systems an inquiry into good hospital governance: A New Zealand-Czech comparison. BioMed Central, 10, 1-10. https://doi.org/10.1186/1478-4505-4-2

9. Fahy, Martin, et al. (2005). Beyond governance: creating corporate value through performance, conformance, and responsibility. England: John Wiley and Sons Ltd.

10. Fayol, Henri. (1986). General and industrial management. The Academy of Management Review, Vol. 11, No. 2 (Apr., 1986), pp. 454-456

11. Ferreira, M., \& Proença, J. (2015). Strategic planning and organizational effectiveness in social service organizations in Portugal. Management, 20(2), 1-21.

12. Gamm LD. (1996). Dimensions of accountability for not-for-profit hospitals and health systems. Health Care Management Review. 21(2):74-86]

13. Gillies. (1992). Technology transfer: a communication perspective. https://www.cjconline.ca/index.php/journal/article/view/690/596

14. Godwin, A., Handsome, O. E., Ayomide, W. A., Enobong, A. E., \& Johnson, F. O. (2017). Application of the henri fayol principles of management in startup organizations. IOSR Journal of Business and Management, 19(10), 7885. https://doi.org/10.9790/487X-1910047885

15. Holland, Thomas P, et al. (1997). Improving board effectiveness: practical lessons for nonprofit health care organizations ( $\mathrm{j}-\mathrm{b}$ aha press) 1 st edition. J-B AHA Press

16. Huntington, Dale \& Khrisna Hort. (2015). Public hospital governance in Asia and The Pacific. 
Comparative Country Studies, Vol. 1 No. 12015 WHO

17. Hunton, James E \& Carolyn Strand Norman. (2010). The impact of alternative

18. Indonesia, P. (2015). Pedoman organisasi rumah sakit.

19. Johanson, R. (2003). Case study methodology. International conference "methodologies in housing research" organised by The Royal Institute of Technology in cooperation with The International Association of People-Environment Studies, Stockholm, 22-24 September 20

20. TeleworkArrangements on OrganizationalCommitment: Insights from a Longitudinal. (2017) Journal of Information Systems. Vol. 24, No. 1 DOI: 10.2308/jis.2010.24.1.67

21. Komisi Akreditasi Rumah Sakit. Efektif 1 Januari 2018. Standar Nasional Akreditasi Rumah Sakit, 1,421

22. Komisi Akreditasi Rumah Sakit. (2017). Standar Nasional Akreditasi Rumah Sakit (SNARS) edisi 1, Jakarta: KAR

23. Likert, R. (1961). New Patterns of Management. New York, NY, US: McGraw-Hill

24. Lotte Scholten. (2003). The Role of Instrumental and Expressive Social Ties in Employees' Perceptions of Organizational Justice. https://doi.org/10.1287/orsc.14.6.738.24865

25. Mallin, Christine. (2010). Corporate Governance. UK: Oxford University Press

26. Marume, S. B. M., \& Jubenkanda, R. R. (2016). The basic concepts and principles of unity of command and the span of control. International Journal of Business and Management Invention, 5(6), 14-18.

27. McGrath, S. K., \& Whitty, S. J. (2018). Accountability and responsibility defined. International Journal of Managing Projects in Business, 11(3), 687-707.

28. McSherry, Wilfred. (2008). The Ethical Basis of Teaching Spirituality and Spiritual Care: A Survey of Student Nurses Perceptions. https://doi.org/10.1016/j.nedt.2008.05.013

29. Michael G. DeGroote School of Business, McMaster University, Ontario, Canada. (2000). The International Journal of Pubic Sector Management, Vol. 13 No. 2, 2000 pp. 108-124. MCB University Press

30. Mulyati, L., Rachman, D., \& Herdiana, Y. (2016). Fakor Determinan yang Memengaruhi Budaya Keselamatan Pasien di RS Pemerintah Kabupaten Kuningan Determinant factors that are Influencing Patient Safety Culture in a Government-owned Hospitals in Kuningan Regency. Jurnal Keperawatan Padjadjaran, 4(2), 179-190

31. Nurdiani, N. (2014). Teknik Sampling Snowball dalam Penelitian Lapangan. ComTech: Computer, Mathematics and Engineering Applications, 5(2), 1110. https://doi.org/10.21512/comtech.v5i2.2427

32. Pat Bradshaw, Vic Murray, Jacob Wolpin. (1992). Do Nonprofit Boards Make a Difference? An Exploration of the Relationships Among Board Structure, Process, and Effectiveness. Research Article https://doi.org/10.1177/089976409202100304

33. Pointer, Dennis D. \& James E. Orlikoff. (1999). Board Work: Governing Health Care Organizations. USA: Jossey-Bass

34. RI, K. K. (2004). Peraturan Menteri Kesehatan RI Nomor 1173 Tahun 2004 tentang Rumah Sakit Gigi dan Mulut.

35. Robbins, Stephen P., Coulter, Mary. (2010). Manajemen Edisi Kesepuluh. Jakarta: Penerbit Erlangga.

36. RSKGM. (2017). Pelatihan 2019 RSKGM. Rumah Sakit Khusus Gigi dan Mulut Fakultas Kedokteran Gigi Universitas Indonesia.

37. RSKGM. (2018). Laporan Kegiatan Rumah Sakit Khusus Gigi dan Mulut Fakultas Kedokteran Gigi Universitas Indonesia.

38. RSKGM. (2018). Renstra RSKGM 2015-2019. Rumah Sakit Khusus Gigi dan Mulut Fakultas Kedokteran Gigi Universitas Indonesia.

39. RSKGM. (2019). Data Staf RSKGM FKG UI. Rumah Sakit Khusus Gigi dan Mulut Fakultas Kedokteran Gigi Universitas Indonesia.

40. RSKGM. (2019). Kualifikasi, Uraian, Tanggung Jawab Wewenang. Rumah Sakit Khusus Gigi dan Mulut Fakultas Kedokteran Gigi Universitas Indonesia.

41. RSKGM. (2019). Hospital Bylaws. Rumah Sakit Khusus Gigi dan Mulut Fakultas Kedokteran Gigi Universitas Indonesia.

42. RSKGM. (2019). Struktur Organisasi RSKGM FKG UI. Rumah Sakit Khusus Gigi dan Mulut Fakultas Kedokteran Gigi Universitas Indonesia.

43. Sadia, A., Mohd Salleh, B., Abdul Kadir, Z., \& Sanif, S. (2017). The Relationship between Organizational Communication and Employees Productivity with New Dimensions of Effective Communication Flow. Journal of Business and Social Review in Emerging Economies, 2(2), 93. https://doi.org/10.26710/jbsee.v2i2.35

44. Savedoff, W. D. (2011). Governance in the Health Sector A Strategy for Measuring Determinants and Performance. (May).

45. Scholten, G., Creemers, L. M., Moen, J., \& Bal, R. (2018). Structuring ambiguity in hospital governance. (August), 1-15. https://doi.org/10.1002/hpm.2693

46. Shortell, Stephen M. et al. (1996). Leadership for Quality Improvement in Health Care: Empirical Evidence on Hospital Boards, Managers, and Physicians Research Article 
https://doi.org/10.1177/107755879605300402

47. Sitohang, E. (2014). Prinsip hukum dalam tata kelola rumah sakit. Fakultas Hukum Universitas Mahendradatta, 29 No.1, 83-99.

48. Tabish, S. A. (2012). Healthcare: From Good to Exceptional Governance. 25(3), 147-149.

49. Umbdenstock, Richard J. , Winifred M. Hageman. (1991). Critical Readings for Hospital Trustees. Health Forum

50. Undang Undang No 36 Tahun 2009 Tentang Kesehatan. , (2009).

51. Undang Undang Nomor 44 Tahun 2009 Tentang Rumah Sakit. , (2009).

52. Universitas Indonesia. SK708-2011 Pengangkatan Ketua Unit Usaha Akademik di UI.pdf.

53. Warliazasusi, J. (2019). Analisis Perencanaan Strategis, Rencana Strategis dan Manajemen Strategis STAIN Curup 2015-2019. 2(2).

54. World Health Organisation. (1946). Preamble to The Consitution Of The World Health Organisation Of The World Health Organisation As Adopted By The International Health Conference; Signed On 22 July 1946 by The Representative Of 61 States And Entered Into Foce On 7 April 1948. International Health Conference, (2), 100. Retrieved from https://www.who.int/governance/eb/who_constitut ion_en.pdf

55. Wayne Taylor, D. (2002). Facts, myths and monsters: understanding the principles of good governance. International Journal of Public Sector Management, 13(2), 108-124. https://doi.org/10.1108/09513550010338755

56. Zareen Husain. (2013). Effective Communication brings successful organizational change. The Business \& Management Review, 3(2), 43-50. Retrieved from http://www.abrmr.com/myfile/conference_proceed ings/Con_Pro_12315/7-

dubai13.pdf\%0Afile:///C:/Users/Kathi/Documents/ Trish/CSFS/Additional Literature/Effective communication brings successful organizational change.pdf 